\title{
Working
}

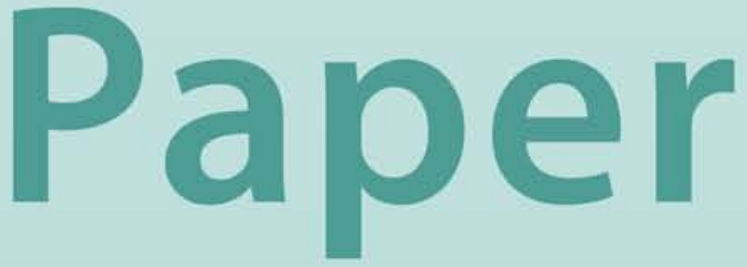


Japan's Quest for Growth: Exploring the Role of Capital and Innovation

\author{
Murtaza Syed and Jinsook Lee
}




\title{
IMF Working Paper
}

Asian Pacific Department

\section{Japan's Quest for Growth: Exploring the Role of Capital and Innovation}

\author{
Prepared by Murtaza Syed and Jinsook Lee ${ }^{1}$
}

Authorized for distribution by Kenneth Kang

[December] 2010

\begin{abstract}
This Working Paper should not be reported as representing the views of the IMF.

The views expressed in this Working Paper are those of the author(s) and do not necessarily represent those of the IMF or IMF policy. Working Papers describe research in progress by the author(s) and are published to elicit comments and to further debate.
\end{abstract}

As labor input in Japan shrinks with population aging, capital accumulation and productivity gains will drive growth over the medium-term. At the same time, a changing global landscape calls for a shift in export-oriented investment toward new markets and a new generation of products, as well as increased investment by domestically-oriented firms. What policies could be adopted to help firms adjust to the imperatives of the post-crisis global economy and boost medium-term growth? Using disaggregated data, this paper investigates the determinants of investment and R\&D spending by Japanese firms. The results suggest that policies could usefully focus on four areas. First, raising the return on investment, including through reforms to the tax code. Second, decreasing uncertainty through improved risk management by firms and by bolstering the business climate. Third, improving SME access to finance, notably by encouraging venture capital investment in innovative areas and more risk-based lending. And fourth, reducing excess leverage and supporting corporate restructuring to enable new investments to flourish.

JEL Classification Numbers: E22, E61

Keywords: Japan, Investment, Capital, Innovation

Author’s E-Mail Address: msyed@imf.org, jlee@imf.org

\footnotetext{
${ }^{1}$ Asia and Pacific Department. We would like to thank, without implicating, Stephan Danninger, James Gordon, Kenneth Kang, Kalpana Kochhar, and participants at seminars hosted by ESRI and RIETI in Tokyo.
} 


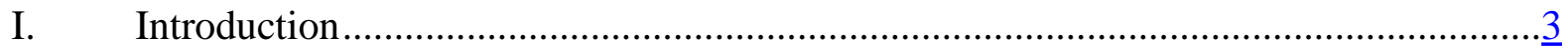

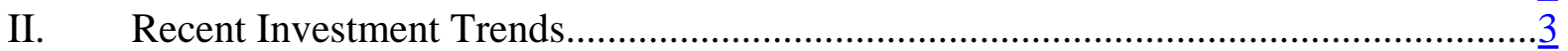

A. Fixed Investment........................................................................................

B. R\&D Spending ....................................................................................

III. Econometric Analysis: What Explains these Trends? .............................................

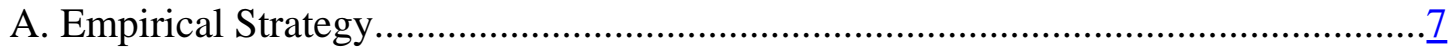

B. Results: Fixed Investment .....................................................................

C. Results: R\&D Spending ..........................................................................

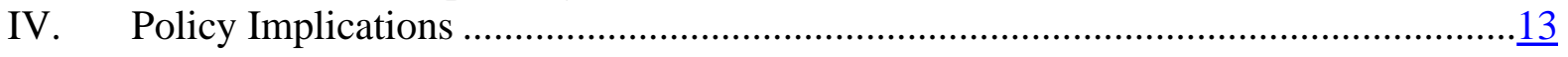

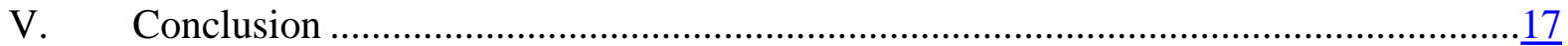

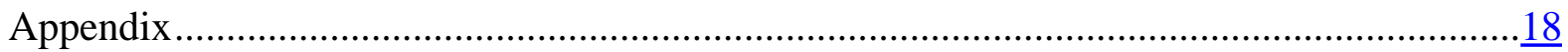

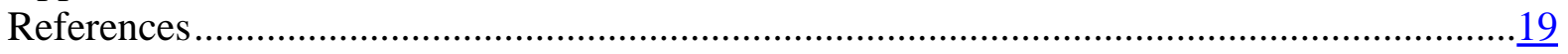

\section{Tables}

1. Non-Financial Corporate Indicators …................................................................ $\underline{5}$

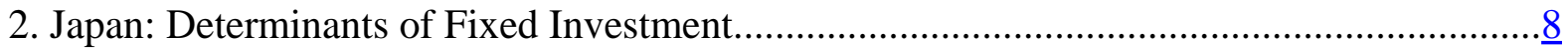

3. Selected Advanced Economies: Determinants of Fixed Investment ................................11

4. Japan: Determinants of R\&D Spending ............................................................... 12

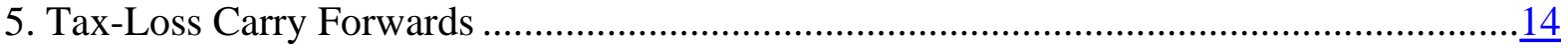

Figures

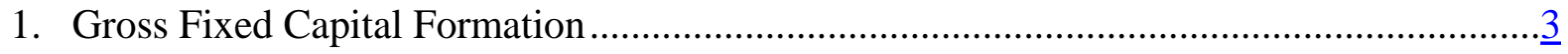

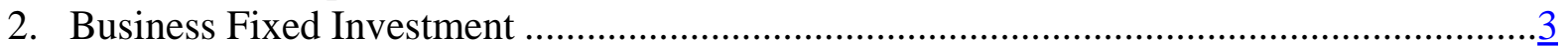

3. Japan: Total Investment by Sector .........................................................................

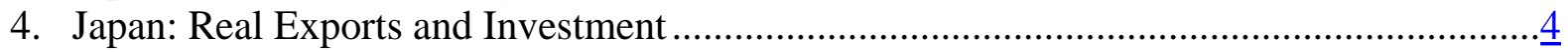

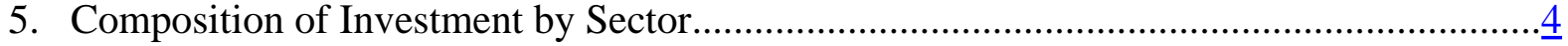

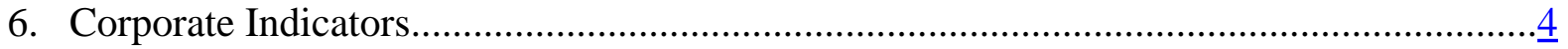

7. Net Capital Stock per Person Employed.................................................................... $\underline{5}$

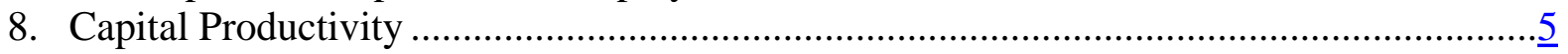

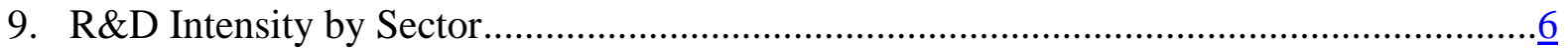

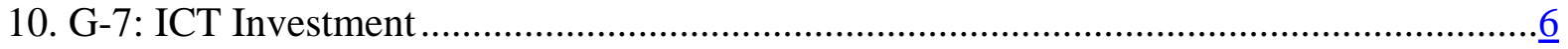

11. Japan: Investment, Liquidity, and Leverage ............................................................

12. Japan: Elasticity of Fixed Investment to Fundamentals .................................................. $\underline{9}$

13. Japan: Elasticity of R\&D Investment to Fundamentals............................................12

14. Effective Corporate Tax Rates in OECD .............................................................

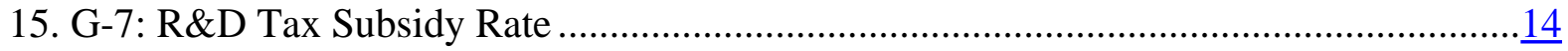

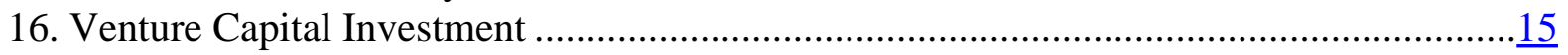

17. Souces of Funds for Venture Capital ................................................................ 15

18. SMEs in Early Growth Phase: Desired and Actual Sources for R\&D ...........................16

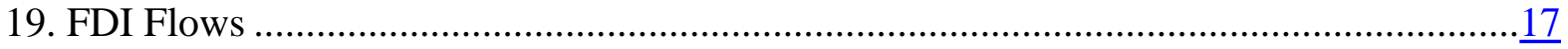




\section{INTRODUCTION}

Promoting investment and technological innovation will be crucial for raising Japan's medium-term growth prospects. As population aging shrinks the labor force, capital accumulation and productivity gains will drive potential growth. However, a transformed post-crisis landscape is likely to necessitate some compositional shifts. First, investment by manufacturing exporters will need to be re-oriented toward products demanded by emerging markets to keep the external engine of growth robust. Second, the domestic sector will need to become another driver for growth, necessitating increased investments in services and domestically-oriented firms. Third, continued innovation will be critical to maintaining Japan's competitive advantage in global markets and boosting profitability and wages.

This paper explores ways to facilitate the adjustment in investment patterns required over the medium-term. Using disaggregated data on listed companies between 1990-2008, the paper investigates the role of economic fundamentals-expected profitability, access to external financing, capital structure, and uncertainty-in determining the investment behavior of Japanese firms. Both tangible and intangible capital are considered-in the form of fixed investment (plant, machinery and equipment) and R\&D—and the main findings are compared with those from other advanced economies. Based on these results, we discuss potential policies that could support Japanese investment in the post-crisis global economy.

\section{RECENT INVESTMENT TRENDS}

\section{A. Fixed Investment}

At first blush, investment does not seem low in Japan or an obvious candidate for policy intervention. After declining almost continuously until the early 2000s, investment has stabilized, and at around 23 percent of GDP is close to the OECD average (Figure 1). Fixed investment has fallen by some 9 percent of GDP since 1990, with private investment accounting for 70 percent of the decline. Following the asset bubble burst, residential construction and spending on plant and equipment have fallen by some $2 \frac{1}{2}$ and $4 \frac{1}{2}$ percent of GDP, respectively.

However, the composition of investment has shifted in recent years. During Japan's recovery (2003-07), fixed investment was to a great extent driven by large firms (Figure 2). Moreover,
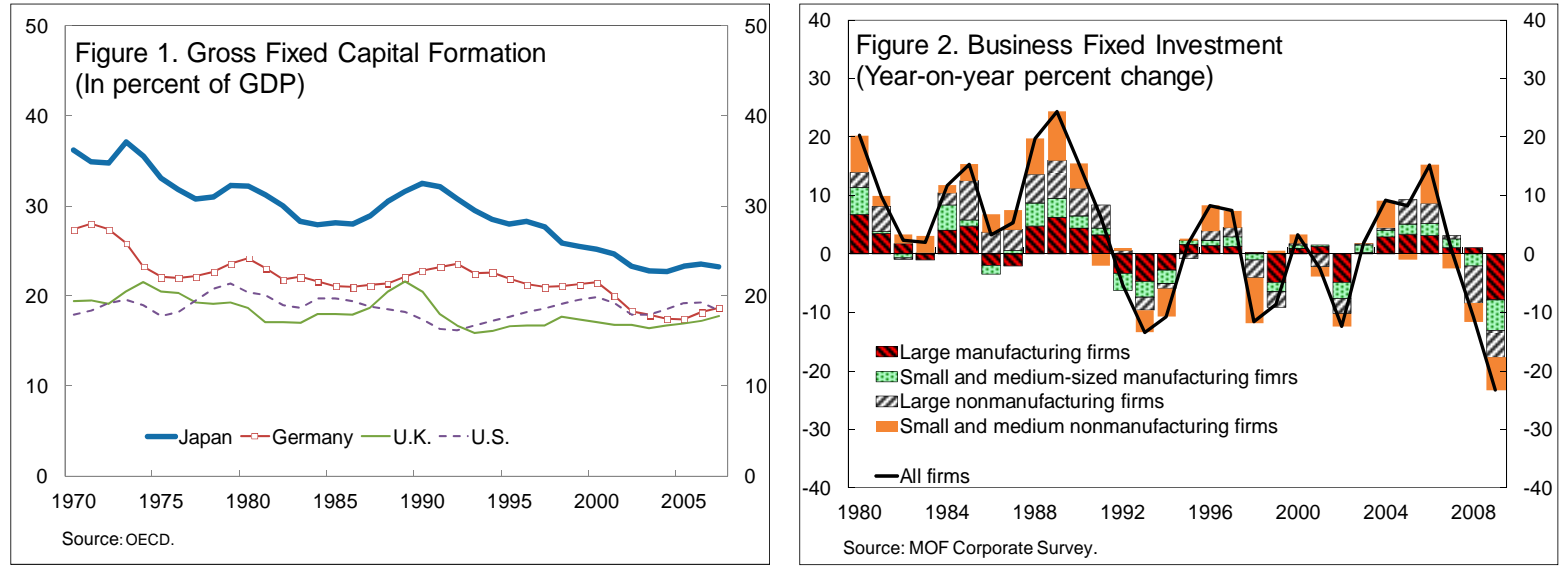
investment shifted markedly toward manufacturing, particularly in the main exporting sectors: automobiles, machinery, electronics, and steel (Figure 3). The share of these four sectors in total investment rose from 19 to 31 percent between 2000 and 2007. As a result, domestic investment and trading partner demand have become increasingly correlated, magnifying Japan's vulnerability to external shocks. This was dramatically illustrated during the current crisis, with both exports and investment sharply contracting last year (Figure 4).
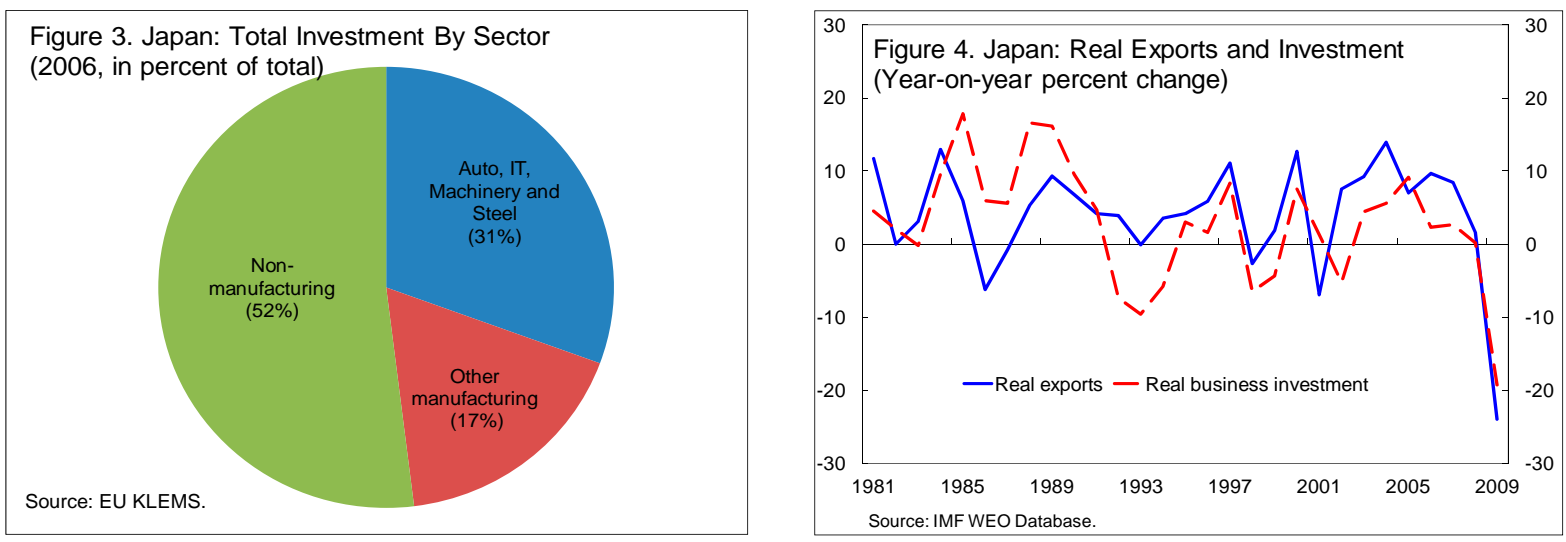

On the other hand, investment by SMEs and firms operating in the services sector has been relatively stagnant in real terms. The share of the non-manufacturing sector in overall investment has fallen from 70 percent in 2000 to just over 50 percent (Figure 5). Despite broadly similar economic structures, this decline contrasts sharply with developments in comparator economies, where the starting share was similar but has now risen to around 80 percent.

These divergent trends are mirrored in the relative strength of economic fundamentals of firms (Figure 6). ${ }^{1}$ In particular, profitability and liquidity indicators tend to be higher and leverage ratios lower for large firms and in the manufacturing sector. In the wake of Japan's banking crisis, these firms, especially exporters, restructured aggressively and enjoyed a long boom from 2003 to 2007. However, firms in more protected areas of the domestic economy - such as health, education, wholesale and retail trade, transport, and utilities-fell behind (Jones and Yoon, 2006).
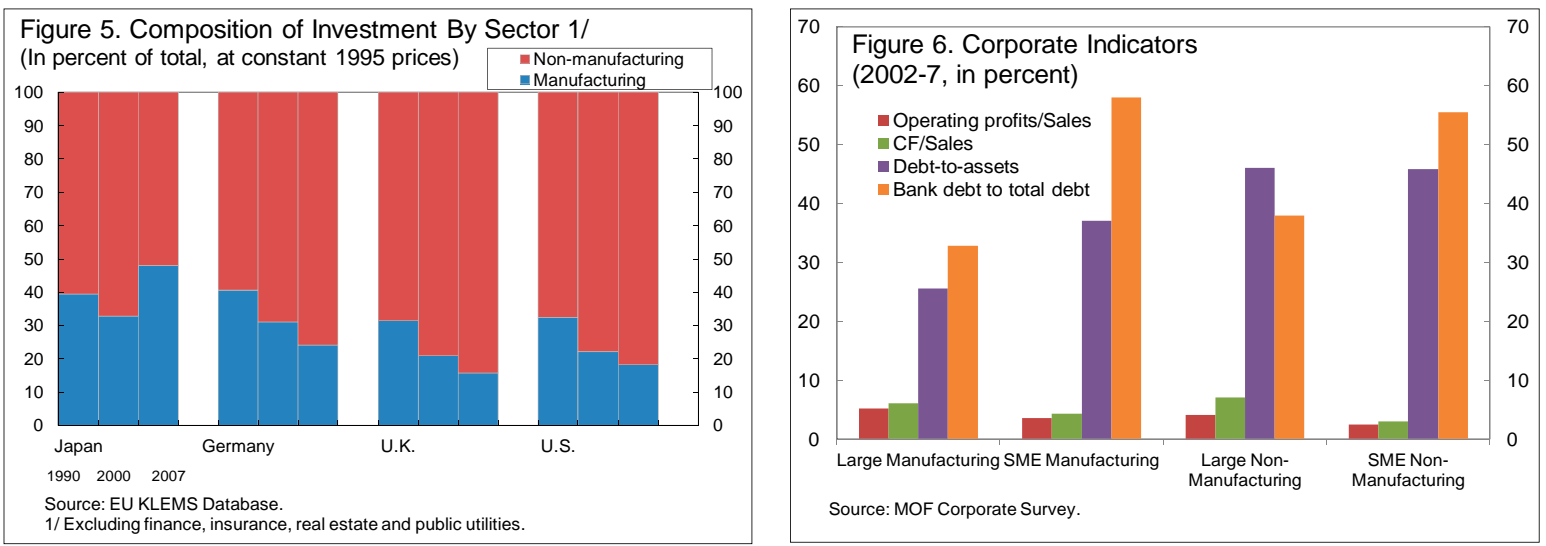

\footnotetext{
${ }^{1}$ For more details, see Bank of Japan (2003), Kang (2003), Komori (2004) and Steinberg (2009).
} 
That said, corporate indicators also tend to be weak by international standards (Table 1). This difference is particularly large in the non-manufacturing sector and compared to U.S. and U.K. firms. Differences in capital structure are similarly stark, with Japanese firms tending to rely much more on debt (particularly bank) financing ${ }^{2}$, and reliance on short-term financing increasing over time.

\begin{tabular}{|c|c|c|c|c|c|c|c|c|}
\hline & \multicolumn{8}{|c|}{$\begin{array}{l}\text { Table 1. Non-Financial Corporate Indicators }{ }^{1 /} \\
\text { (In percent) }\end{array}$} \\
\hline & \multicolumn{4}{|c|}{ Manufacturing } & \multicolumn{4}{|c|}{ Non-Manufacturing } \\
\hline & Japan & Germany & U.K. & U.S. & Japan & Germany & U.K. & U.S. \\
\hline \multicolumn{9}{|c|}{ Profitability } \\
\hline \multicolumn{9}{|c|}{ Return on assets } \\
\hline 1990-97 & 2.45 & 3.75 & 7.37 & 6.34 & 2.42 & 4.09 & 6.50 & 6.51 \\
\hline 2000-07 & 2.30 & 4.05 & 3.29 & 1.26 & 2.28 & 3.89 & 5.70 & 5.09 \\
\hline \multicolumn{9}{|l|}{ Liquidity } \\
\hline \multicolumn{9}{|c|}{ Current ratio $2 /$} \\
\hline $1990-97$ & 1.42 & 1.88 & 1.46 & 2.33 & 1.11 & 1.59 & 1.16 & 1.79 \\
\hline $2000-07$ & 1.51 & 1.79 & 1.58 & 2.18 & 1.01 & 1.65 & 1.04 & 1.47 \\
\hline \multicolumn{9}{|c|}{ Leverage } \\
\hline \multicolumn{9}{|c|}{ Debt to equity } \\
\hline $1990-97$ & 70.13 & 54.90 & 37.79 & 32.53 & 79.61 & 82.50 & 29.55 & 41.26 \\
\hline 2000-07 & 44.23 & 43.25 & 26.16 & 20.85 & 68.48 & 79.83 & 48.49 & 33.00 \\
\hline \multicolumn{9}{|c|}{ Short-term debt to total debt } \\
\hline $1990-97$ & 52.47 & 50.23 & 49.81 & 19.35 & 42.31 & 40.69 & 52.41 & 9.58 \\
\hline 2000-07 & 60.86 & 44.49 & 41.69 & 25.70 & 48.04 & 32.73 & 31.36 & 14.34 \\
\hline
\end{tabular}

\section{B. R\&D Spending}

At the same time, capital efficiency is relatively low, pointing to the need for more innovation. The capital-intensity of the Japanese economy has been rising since the 1970s and is high compared to advanced economy peers (Figure 7). However, capital productivity has been on a trend decline and is now appreciably lower than in the United Kingdom and the United States (Figure 8). This suggests the need for more innovation and intangible investment to boost the efficiency of Japan's capital stock, including through R\&D spending.
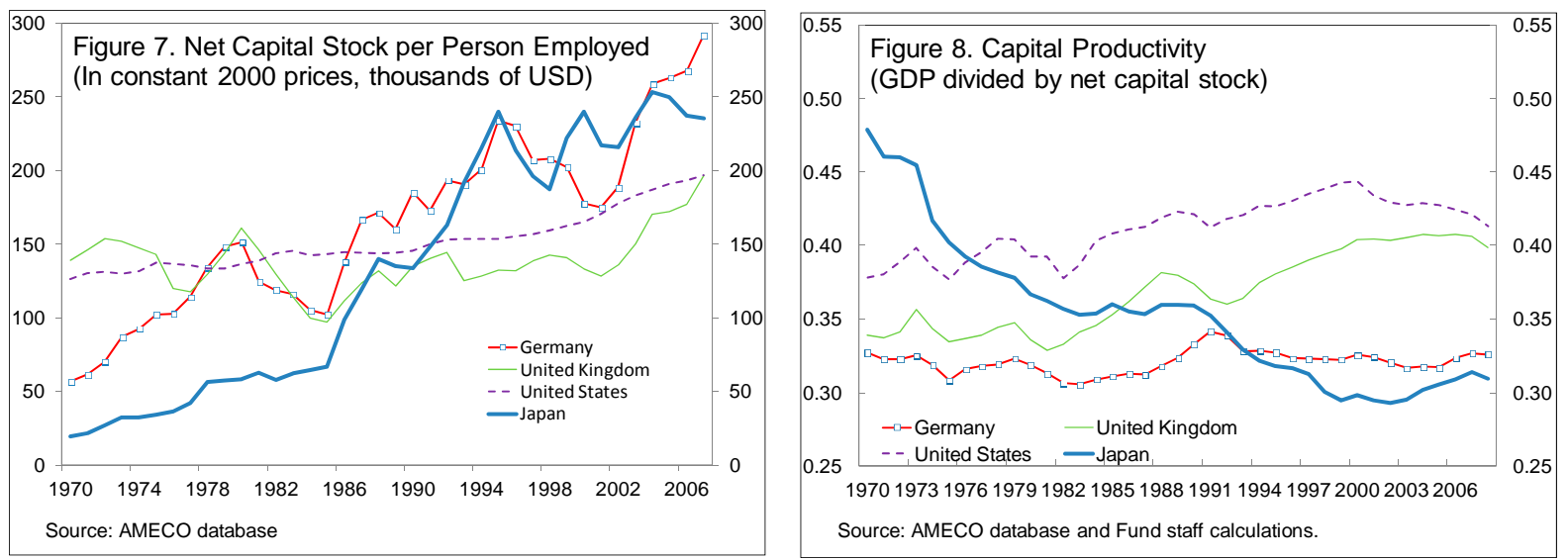

${ }^{2}$ In Japan, bank lending accounts for around 50 percent of corporate financing, compared to around 15 percent in the United States, where stocks and corporate bonds dominate (60 percent) (BoJ, 2003). 
Japanese firms devote significant resources to R\&D spending, but it is skewed toward manufacturing and its impact is generally low (Figure 9). R\&D spending as share of GDP is the third-highest in the OECD, but its benefits in terms of productivity growth have lagged over the last two decades (OECD, 2005; Brandstetter and Nakamura, 2003). ${ }^{3}$ Possible factors include: the waning importance of process and incremental product innovation in which Japan has traditionally excelled and the lack of "radical product innovation” (Sakakibara and Tsujimoto, 2003); vertically integrated structures and weaknesses in areas in which

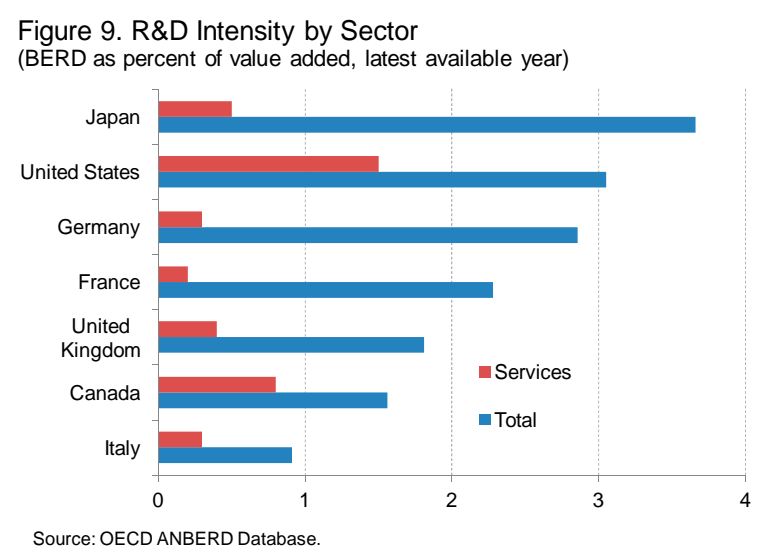
collaboration with a broad range of organizations is critical, ${ }^{4}$ such as services and software (Takeishi and Fujimoto, 2003); weak linkages between R\&D sectors, i.e. universities, businesses and the public sector; a relatively low degree of openness to foreign investment; and the underdeveloped venture capital industry. ${ }^{5}$

The low share of services in business R\&D also stands out and may be contributing to low productivity in the sector-at 12 percent, it is the lowest in the OECD, compared to 43 percent in the United States and an OECD average of 25 percent. By type of investment, information and communication technology (ICT)-related capital spending is low (Figure 10). Investment in ICT products is thought to be particularly important in the service sector, enabling firms to engage in process innovation through the value chain, develop new applications and raise productivity (Nicoletti and Scarpetta, 2005). In the United States, a large proportion of the acceleration in labor productivity since the mid-1990s originated in services that use ICT intensively, including retail, wholesale, finance, and telecommunications. In

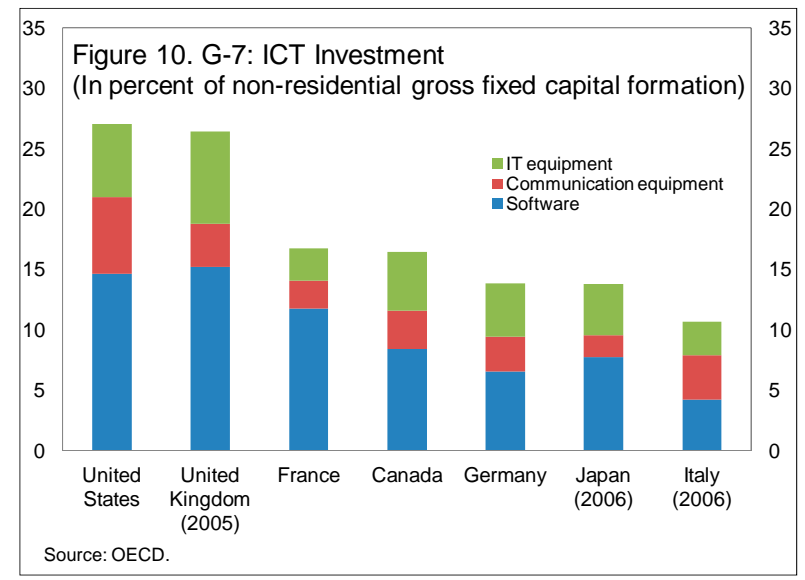

\footnotetext{
${ }^{3}$ For instance, the Science Council of Japan estimates that R\&D efficiency in life science, IT, environment, and nanotechnology is half that in the U.S. and major European countries.

${ }^{4}$ This stands in contrast to areas in which the scale of firms' internal resources and the closeness of their relations with regular business partners/suppliers are important, such as cars and domestic appliances, in which Japanese firms tend to be innovation leaders.

${ }^{5}$ Empirical evidence in the electronics, telecommunications, software and biotech industries suggest that entrants and small companies are more cost-effective producers of innovation and especially successful in introducing "disruptive" technologies that can give rise to new markets. In Japan, for example, there is evidence that younger and smaller companies tend to grow faster (Imai and Kawagoe, 2000).
} 
contrast, the contribution of ICT-using services to labor productivity is low in Japan and has declined significantly since 1995 (OECD, 2008).

These cross-sectional differences in investment motivate the disaggregated nature of our empirical analysis. The next section models what has been driving these trends in fixed capital and R\&D spending in Japan using panel data, and the extent to which their determinants differ across firms and compared to other advanced economies.

\section{ECONOMETRIC ANALYSIS: WHAT EXPLAINS THESE TRENDS?}

\section{A. Empirical Strategy}

Using firm-level panel data on listed companies from the WorldScope database, we estimate the standard neoclassical investment model for fixed capital, and extend it to R\&D for simplicity. ${ }^{6}$ The model relates investment to expectations of future profitability through Tobin's Q, and is augmented by some additional factors in line with the modern investment literature:

$$
\Delta\left(\frac{I}{K}\right)_{i t} \text { or } \Delta\left(\frac{R D}{C}\right)_{i t}=c_{t}+b \Delta Q_{i t}+c \Delta Z_{i, t}+\Delta \varepsilon_{i t}
$$

where the dependent variable is either $\mathrm{I} / \mathrm{K}$ the ratio of fixed investment to the fixed capital stock or $R D / C$ the ratio of $R \& D$ spending to its stock, $Q$ is Tobin's $Q^{7}$, and $Z$ a vector of additional variables, including the lagged dependent variable together with: (i) cash flow divided by capital, which measures the internal funds available to finance investment projects and is typically used in the literature as a proxy for financing constraints; (ii) leverage, measured by the debt-to-assets ratio, reflecting the effect of financial structure on investment; and (iii) the standard deviation of returns on the weekly stock price index to capture the potential negative impact of uncertainty on investment. ${ }^{8}$

The models are estimated using a GMM approach, to allow for endogeneity and measurement error in the dependent variables. Estimations are conducted in first -differences and included year dummies, to control for firm-and time-specific effects. This approach yields consistent estimates provided there is no higher order serial correlation in the residuals and the instruments are valid. ${ }^{9}$ Diagnostic tests are used to verify these conditions. ${ }^{10}$

\footnotetext{
${ }^{6}$ See Appendix for details.

${ }^{7}$ Defined as the ratio of the stock market valuation of the firm to the replacement cost of its capital stock.

8 This is consistent with the "real options" literature emphasize the role of risk, with greater uncertainty providing an incentive to delay investment (Dixit and Pindyck, 1994).

${ }^{9}$ The instruments reported are lagged values of the dependent variable and our regressors, but results were robust to using alternative instrument sets.

${ }^{10}$ Models are assessed based on tests for serial correlation (m1 and m2) and instrument validity (Hansen).
} 


\section{B. Results: Fixed Investment}

At an aggregate level, fixed investment appears to closely track cash flow and leverage in our sample of Japanese firms (Figure 11). The growth rate of the median investment rate is positively correlated with that of cash flow and negatively with that of the debt-to-asset ratio. The turning points are also closely mimicked across these three variables, with a one-period lead in the case of cash flow. While these time-series comovements are suggestive, we model these

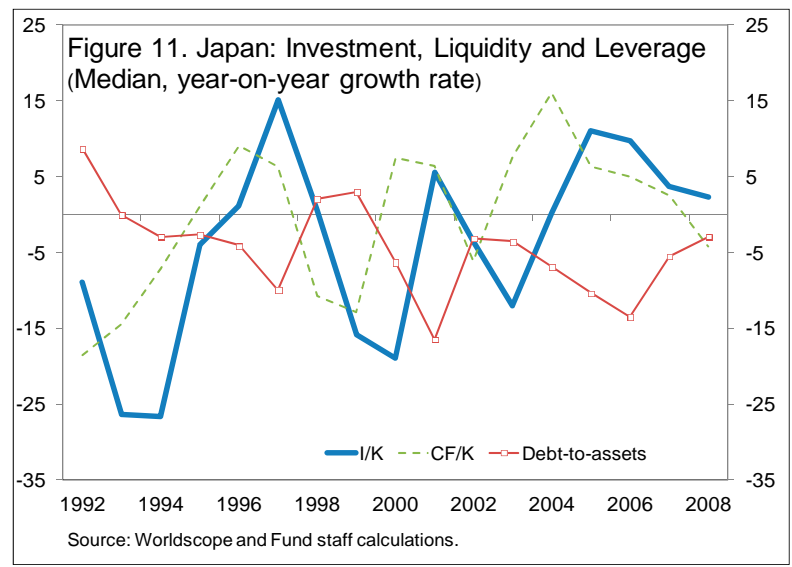
relationships more formally below, allowing for endogeneity.

The empirical model confirms the importance of economic fundamentals for fixed investment. Estimating equation (1) on our full sample, we find (Table 2):

\begin{tabular}{|c|c|c|c|c|c|c|c|c|c|c|c|}
\hline & \multirow[t]{2}{*}{ Full Sample } & \multicolumn{2}{|c|}{ Time period } & \multicolumn{2}{|c|}{ Size } & \multicolumn{2}{|c|}{ Market exposure } & \multicolumn{2}{|c|}{ Factor intensity } & \multicolumn{2}{|c|}{ Sector } \\
\hline & & $1990 \mathrm{~s}$ & $2000 \mathrm{~s}$ & Big & Small & Exporters & Domestic & Capital & Labor & Manufacturing & Services \\
\hline \multirow[b]{2}{*}{ Tobin's Q } & \multicolumn{11}{|c|}{ JAPAN } \\
\hline & $\begin{array}{c}0.007^{\star *} \\
(0.00)\end{array}$ & $\begin{array}{c}0.017^{\star *} \\
(0.01)\end{array}$ & $\begin{array}{l}0.005^{\star} \\
(0.00)\end{array}$ & $\begin{array}{c}0.007^{\star *} \\
(0.00)\end{array}$ & $\begin{array}{l}0.004 \\
(0.00)\end{array}$ & $\begin{array}{c}0.008^{\star \star} \\
(0.00)\end{array}$ & $\begin{array}{l}0.005 \\
(0.00)\end{array}$ & $\begin{array}{l}0.010^{\star *} \\
(0.00)\end{array}$ & $\begin{array}{l}0.004 \\
(0.00)\end{array}$ & $\begin{array}{c}0.012^{\star *} \\
(0.00)\end{array}$ & $\begin{array}{l}0.002 \\
(0.00)\end{array}$ \\
\hline Liquidity $3 /$ & $\begin{array}{l}0.012 \\
(0.04)\end{array}$ & $\begin{array}{l}-0.179 \\
(0.13)\end{array}$ & $\begin{array}{l}0.045 \\
(0.04)\end{array}$ & $\begin{array}{l}-0.046 \\
(0.05)\end{array}$ & $\begin{array}{l}0.089^{*} \\
(0.06)\end{array}$ & $\begin{array}{l}-0.012 \\
(0.04)\end{array}$ & $\begin{array}{l}0.103^{*} \\
(0.06)\end{array}$ & $\begin{array}{l}-0.019 \\
(0.06)\end{array}$ & $\begin{array}{l}0.103^{\star *} \\
(0.05)\end{array}$ & $\begin{array}{l}0.021 \\
(0.06)\end{array}$ & $\begin{array}{l}0.092^{*} \\
(0.06)\end{array}$ \\
\hline Leverage 4 / & $\begin{array}{c}-0.002^{\star *} \\
(0.00)\end{array}$ & $\begin{array}{l}0.000 \\
(0.00)\end{array}$ & $\begin{array}{c}-0.002^{\star *} \\
(0.00)\end{array}$ & $\begin{array}{l}-0.001 \\
(0.00)\end{array}$ & $\begin{array}{c}-0.002^{\star *} \\
(0.00)\end{array}$ & $\begin{array}{l}-0.001 \\
(0.00)\end{array}$ & $\begin{array}{c}-0.001^{*} \\
(0.00)\end{array}$ & $\begin{array}{c}-0.002^{* *} \\
(0.00)\end{array}$ & $\begin{array}{c}-0.002^{\star *} \\
(0.00)\end{array}$ & $\begin{array}{l}-0.001 \\
(0.00)\end{array}$ & $\begin{array}{c}-0.002^{\star *} \\
(0.00)\end{array}$ \\
\hline \multirow[t]{2}{*}{ Uncertainty $5 /$} & $\begin{array}{c}-0.062^{* *} \\
(0.03)\end{array}$ & $\begin{array}{l}-0.033 \\
(0.09)\end{array}$ & $\begin{array}{c}-0.063^{\star *} \\
(0.03)\end{array}$ & $\begin{array}{c}-0.064^{*} \\
(0.03)\end{array}$ & $\begin{array}{l}-0.057 \\
(0.04)\end{array}$ & $\begin{array}{c}-0.054^{\star} \\
(0.03)\end{array}$ & $\begin{array}{l}-0.011 \\
(0.03)\end{array}$ & $\begin{array}{c}-0.088^{\star *} \\
(0.03)\end{array}$ & $\begin{array}{c}-0.064^{\star *} \\
(0.03)\end{array}$ & $\begin{array}{c}-0.070^{\star *} \\
(0.03)\end{array}$ & $\begin{array}{l}-0.024 \\
(0.04)\end{array}$ \\
\hline & \multicolumn{11}{|c|}{ (p-value of specification tests) } \\
\hline $\mathrm{m} 1$ & 0.000 & 0.000 & 0.000 & 0.000 & 0.000 & 0.000 & 0.000 & 0.000 & 0.000 & 0.000 & 0.000 \\
\hline m2 & 0.196 & 0.520 & 0.150 & 0.211 & 0.220 & 0.120 & 0.165 & 0.734 & 0.207 & 0.796 & 0.201 \\
\hline Hansen-test & 0.189 & 0.344 & 0.267 & 0.185 & 0.625 & 0.131 & 0.852 & 0.322 & 0.271 & 0.152 & 0.916 \\
\hline Number of firms & 2695 & 356 & 2529 & 1244 & 1553 & 1014 & 1681 & 1371 & 1395 & 1635 & 1060 \\
\hline Number of observations & 10649 & 1256 & 9393 & 5298 & 4590 & 5102 & 5547 & 4869 & 4465 & 7029 & 3620 \\
\hline \multicolumn{12}{|c|}{$\begin{array}{l}\text { Source: Worldscope and Fund staff calculations. } \\
\text { 1/ First-differenced GMM specifications, with lagged dependent variable and year dummies. Instruments are lagged values of regressors. } \\
\text { 2/ Robust t-statistics in parentheses, with * indicating significance at } 10 \text { percent and ** at } 5 \text { percent level. } \\
\text { 3/ Cash flow to capital. } \\
\text { 4/ Debt-to-assets. }\end{array}$} \\
\hline
\end{tabular}

- $\quad$ Profitability. Investment is positively associated with expectations of future profitability, as summarized by Tobin's Q, with an implied elasticity (estimated at the means of the sample) of 0.2 .

- $\quad$ Leverage and uncertainty. Investment is negatively associated with leverage and uncertainty, with implied elasticities of -0.4 and -0.2 , respectively. 
- $\quad$ Cash flow. The coefficient on cash flow is positive but insignificant, suggesting that the average listed firm in Japan is not financially constrained, consistent with the large excess cash holdings typically observed at large firms.

However, the determinants of investment have changed over time. Declining investment rates during the early part of our sample seem to mainly reflect diminished profit expectations. In particular, we find no evidence of any association with cash flow or leverage ratios. While this may reflect large standard errors due to the smaller size of the sub sample, the magnitude of the coefficients is also very different from that in the 2000s. These findings are consistent with the hypothesis that low demand for investment due to declining profitability was the key constraint during the 1990s. ${ }^{11}$ By contrast, the stronger relationships observed between investment, leverage and uncertainty in the full sample seem to reflect the behavior of Japanese companies during the more recent period.

Factors driving investment also differ significantly based on firm characteristicsincluding size, sector, overseas exposure, and capital intensity (Figure 12):

- $\quad$ Large firms. For larger firms, manufacturers, exporters, and those using capital-intensive technology, profit expectations and uncertainty have powerful effects on investment. This may reflect their greater

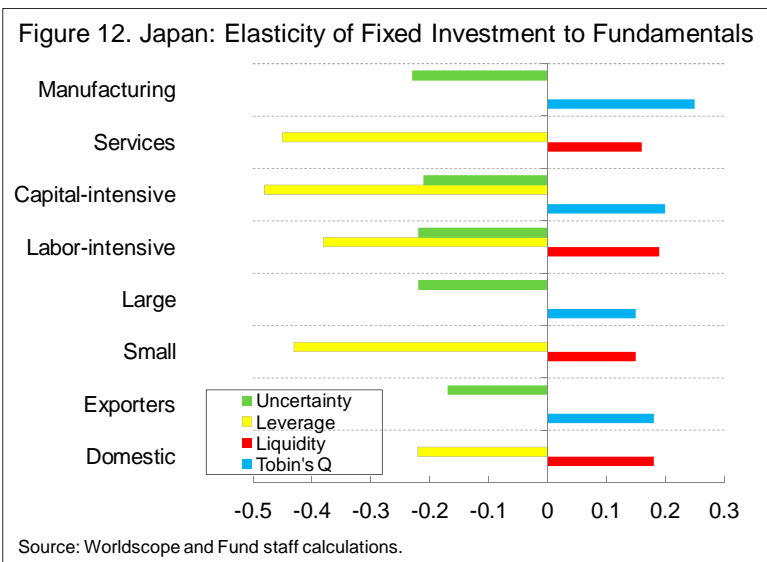
exposure to international competition, as well as to fluctuations in domestic and overseas macroeconomic conditions.

- $\quad$ SMEs. By contrast, for smaller firms, service providers ${ }^{12}$, non-exporters, and those utilizing labor-intensive technology, investment is more sensitive to cash flow. This cross-sectional variation in the coefficient on cash flow supports its interpretation as an indicator of financing constraints. ${ }^{13}$

- Leverage. Despite progress with corporate restructuring, a legacy of excess leverage and dependence on debt financing continues to hold back investment for the smaller group of firms. In splitting the sample by debt reliance and the magnitude of Tobin's $\mathrm{Q}$, we found this effect to be concentrated in those firms with a high debt and low profitability, suggesting threshold effects.

\footnotetext{
${ }^{11}$ This is consistent with the hypothesis in Hayashi and Prescott (2002), among others.

${ }^{12}$ This includes medical and healthcare, wholesale and retail trade, construction, power supply, transport, and telecommunications.

${ }^{13}$ Similar results were obtained in dividing the sample by the age of the firm, with younger firms found to be financially constrained.
} 
Moreover, the economic significance of these effects appears large. The estimated elasticities suggest: ${ }^{14}$

- $\quad$ Large firms. A 10 percent increase in expected profitability or a 10 percent decline in uncertainty could increase real investment of large firms by $1 \frac{1 / 2}{2}$ and 2 percent, respectively.

- $\quad S M E s$. A 10 percent improvement in access to external financing or a 10 percent decline in leverage could increase SME investment in real terms by $1 \frac{1 / 2}{2}$ and 4 percent, respectively.

- $\quad$ Manufacturing. A 10 percent increase in expected profitability or a 10 percent decline in uncertainty could both increase manufacturing investment by $2 \frac{1}{2} 2$ percent in real terms.

- $\quad$ Services. A 10 percent improvement in access to external financing or a 10 percent decline in leverage could increase real investment in the service sector by $1 \frac{1 / 2}{2}$ and 4 percent, respectively.

A cross-country analysis shows that while the behavior of German firms is qualitatively similar to Japan, the determinants of investment in the United Kingdom and the United States are markedly different (Table 3). The significant impact of profit expectations and uncertainly on investment by larger firms and those in the export sector is also observed in these other advanced economies. Apart from this, however, there are few similarities between Japan and Germany on the one hand and the United States and the United Kingdom on the other. Operating in a similar bank-centric environment, German firms display much the same cross-sectional pattern in financing constraints. However, there is little evidence of such constraints or detrimental effects of debt financing in the case of U.S. and U.K. firms in recent years, perhaps reflecting abundant liquidity leading up to the current crisis as well as more diverse sources of corporate funding for small companies (beyond bank lending).

\footnotetext{
${ }^{14}$ The 10 percent shocks below are considered at the means of the explanatory variables, and correspond to standard deviation shifts of: (i) one-tenth for Tobin's, cash flow, and leverage; and (ii) one-third for uncertainty.
} 


\begin{tabular}{|c|c|c|c|c|c|c|c|c|c|c|c|}
\hline & \multirow[t]{2}{*}{ Full Sample } & \multicolumn{2}{|c|}{ Time period } & \multicolumn{2}{|c|}{ Size } & \multicolumn{2}{|c|}{ Market exposure } & \multicolumn{2}{|c|}{ Factor intensity } & \multicolumn{2}{|c|}{ Sector } \\
\hline & & 1990s & $2000 \mathrm{~s}$ & Big & Small & Exporters & Domestic & Capital & Labor & Manufacturing & Services \\
\hline & \multicolumn{11}{|c|}{ GERMANY } \\
\hline Tobin's Q & $\begin{array}{c}0.011^{\star *} \\
(0.00)\end{array}$ & $\begin{array}{c}0.006^{* *} \\
(0.00)\end{array}$ & $\begin{array}{c}0.014^{\star \star} \\
(0.00)\end{array}$ & $\begin{array}{l}0.009^{\star} \\
(0.00)\end{array}$ & $\begin{array}{c}0.014^{\star *} \\
(0.01)\end{array}$ & $\begin{array}{l}0.005 \\
(0.00)\end{array}$ & $\begin{array}{c}0.022^{\star *} \\
(0.01)\end{array}$ & $\begin{array}{c}0.026^{* *} \\
(0.01)\end{array}$ & $\begin{array}{c}0.021^{\star *} \\
(0.01)\end{array}$ & $\begin{array}{c}0.006^{\star *} \\
(0.01)\end{array}$ & $\begin{array}{c}0.023^{\star *} \\
(0.01)\end{array}$ \\
\hline Liquidity $3 /$ & $\begin{array}{l}0.022 \\
(0.02)\end{array}$ & $\begin{array}{c}-0.027 \\
(0.10)\end{array}$ & $\begin{array}{c}0.029^{\star} \\
(0.02)\end{array}$ & $\begin{array}{c}-0.019 \\
(0.05)\end{array}$ & $\begin{array}{l}0.034^{*} \\
(0.02)\end{array}$ & $\begin{array}{r}-0.006 \\
(0.04)\end{array}$ & $\begin{array}{c}0.038^{\star} \\
(0.02)\end{array}$ & $\begin{array}{c}-0.039 \\
(0.03)\end{array}$ & $\begin{array}{l}0.035^{*} \\
(0.02)\end{array}$ & $\begin{array}{l}0.037 \\
(0.03)\end{array}$ & $\begin{array}{c}0.034^{\star \star} \\
(0.02)\end{array}$ \\
\hline Leverage $4 /$ & $\begin{array}{c}-0.001 \\
(0.00)\end{array}$ & $\begin{array}{c}-0.002 \\
(0.00)\end{array}$ & $\begin{array}{l}-0.001 \\
(0.00)\end{array}$ & $\begin{array}{r}-0.000 \\
(0.00)\end{array}$ & $\begin{array}{c}-0.002^{*} \\
(0.00)\end{array}$ & $\begin{array}{l}-0.000 \\
(0.00)\end{array}$ & $\begin{array}{c}-0.002 \\
(0.00)\end{array}$ & $\begin{array}{l}0.002 \\
(0.00)\end{array}$ & $\begin{array}{c}-0.004^{\star *} \\
(0.00)\end{array}$ & $\begin{array}{l}0.001 \\
(0.00)\end{array}$ & $\begin{array}{c}-0.000 \\
(0.00)\end{array}$ \\
\hline \multirow[t]{2}{*}{ Uncertainty $5 /$} & $\begin{array}{l}0.018 \\
(0.06)\end{array}$ & $\begin{array}{l}-0.002 \\
(0.22)\end{array}$ & $\begin{array}{l}0.033 \\
(0.07)\end{array}$ & $\begin{array}{c}-0.103^{* *} \\
(0.05)\end{array}$ & $\begin{array}{l}0.055 \\
(0.05)\end{array}$ & $\begin{array}{c}-0.084^{*} \\
(0.05)\end{array}$ & $\begin{array}{l}0.035 \\
(0.06)\end{array}$ & $\begin{array}{c}-0.091^{*} \\
(0.05)\end{array}$ & $\begin{array}{l}0.103 \\
(0.08)\end{array}$ & $\begin{array}{l}0.077 \\
(0.09)\end{array}$ & $\begin{array}{l}0.031 \\
(0.05)\end{array}$ \\
\hline & \multicolumn{11}{|c|}{ (p-value of specification tests) } \\
\hline m1 & 0.000 & 0.007 & 0.001 & 0.000 & 0.000 & 0.001 & 0.000 & 0.000 & 0.000 & 0.004 & 0.001 \\
\hline $\mathrm{m} 2$ & 0.103 & 0.354 & 0.150 & 0.264 & 0.163 & 0.194 & 0.175 & 0.316 & 0.876 & 0.203 & 0.128 \\
\hline Hansen-test & 0.532 & 0.623 & 0.677 & 0.584 & 0.265 & 0.642 & 0.695 & 0.578 & 0.705 & 0.639 & 0.136 \\
\hline Number of firms & 717 & 330 & 634 & 336 & 437 & 484 & 233 & 375 & 170 & 395 & 322 \\
\hline \multirow{2}{*}{ Number of observations } & 4548 & 1453 & 3095 & 2258 & 1978 & 3490 & 1058 & 2078 & 678 & 2852 & 1696 \\
\hline & \multicolumn{11}{|c|}{ UNITED KINGDOM } \\
\hline Tobin's Q & $\begin{array}{c}0.010^{* *} \\
(0.00)\end{array}$ & $\begin{array}{l}0.011 \\
(0.01)\end{array}$ & $\begin{array}{c}0.010^{* *} \\
(0.00)\end{array}$ & $\begin{array}{c}0.008^{\star *} \\
(0.00)\end{array}$ & $\begin{array}{c}0.015^{\star *} \\
(0.00)\end{array}$ & $\begin{array}{c}0.007^{\star *} \\
(0.00)\end{array}$ & $\begin{array}{c}0.015^{\star *} \\
(0.00)\end{array}$ & $\begin{array}{c}0.028^{* *} \\
(0.01)\end{array}$ & $\begin{array}{c}0.013^{\star *} \\
(0.00)\end{array}$ & $\begin{array}{l}0.007^{*} \\
(0.00)\end{array}$ & $\begin{array}{c}0.013^{* *} \\
(0.00)\end{array}$ \\
\hline Liquidity $3 /$ & $\begin{array}{l}0.000 \\
(0.02)\end{array}$ & $\begin{array}{c}0.070^{\star *} \\
(0.03)\end{array}$ & $\begin{array}{c}-0.010 \\
0.023\end{array}$ & $\begin{array}{l}-0.011 \\
(0.02)\end{array}$ & $\begin{array}{l}0.014 \\
(0.01)\end{array}$ & $\begin{array}{l}0.005 \\
(0.01)\end{array}$ & $\begin{array}{l}0.028 \\
(0.03)\end{array}$ & $\begin{array}{l}0.044 \\
(0.03)\end{array}$ & $\begin{array}{l}-0.018 \\
(0.02)\end{array}$ & $\begin{array}{l}0.019 \\
(0.01)\end{array}$ & $\begin{array}{l}-0.031 \\
(0.03)\end{array}$ \\
\hline Leverage 4 / & $\begin{array}{l}0.000 \\
(0.00)\end{array}$ & $\begin{array}{l}-0.000 \\
(0.00)\end{array}$ & $\begin{array}{l}0.001 \\
(0.00)\end{array}$ & $\begin{array}{l}-0.000 \\
(0.00)\end{array}$ & $\begin{array}{c}-0.001 \\
(0.00)\end{array}$ & $\begin{array}{c}-0.001 \\
(0.00)\end{array}$ & $\begin{array}{c}-0.001 \\
(0.00)\end{array}$ & $\begin{array}{l}0.000 \\
(0.00)\end{array}$ & $\begin{array}{c}-0.000 \\
(0.00)\end{array}$ & $\begin{array}{l}0.000 \\
(0.00)\end{array}$ & $\begin{array}{l}-0.000 \\
(0.00)\end{array}$ \\
\hline \multirow[t]{2}{*}{ Uncertainty $5 /$} & $\begin{array}{c}-0.102^{\star *} \\
(0.05)\end{array}$ & $\begin{array}{l}-0.034 \\
(0.05)\end{array}$ & $\begin{array}{c}-0.129^{* *} \\
(0.06)\end{array}$ & $\begin{array}{c}-0.135^{\star *} \\
(0.05)\end{array}$ & $\begin{array}{c}-0.069^{\star} \\
(0.04)\end{array}$ & $\begin{array}{l}-0.058 \\
(0.05)\end{array}$ & $\begin{array}{c}-0.106^{*} \\
(0.06)\end{array}$ & $\begin{array}{c}-0.106^{* *} \\
(0.06)\end{array}$ & $\begin{array}{c}-0.131^{\star *} \\
(0.06)\end{array}$ & $\begin{array}{c}-0.082^{* *} \\
(0.04)\end{array}$ & $\begin{array}{c}-0.087^{*} \\
(0.05)\end{array}$ \\
\hline & \multicolumn{11}{|c|}{ ( $p$-value of specification tests) } \\
\hline m1 & 0.000 & 0.002 & 0.000 & 0.000 & 0.000 & 0.000 & 0.000 & 0.000 & 0.000 & 0.000 & 0.000 \\
\hline $\mathrm{m} 2$ & 0.148 & 0.165 & 0.546 & 0.187 & 0.166 & 0.149 & 0.152 & 0.201 & 0.090 & 0.199 & 0.194 \\
\hline Hansen-test & 0.548 & 0.425 & 0.858 & 0.327 & 0.672 & 0.312 & 0.163 & 0.688 & 0.210 & 0.402 & 0.443 \\
\hline Number of firms & 1664 & 1035 & 1197 & 792 & 1000 & 1224 & 440 & 906 & 982 & 672 & 992 \\
\hline \multirow{2}{*}{ Number of observations } & 10530 & 4629 & 5901 & 5152 & 4693 & 8507 & 2203 & 4746 & 4563 & 4716 & 5814 \\
\hline & \multicolumn{11}{|c|}{ UNITED STATES } \\
\hline Tobin's Q & $\begin{array}{c}0.010^{\star *} \\
(0.00)\end{array}$ & $\begin{array}{l}0.015^{*} \\
(0.01)\end{array}$ & $\begin{array}{c}0.010^{\star *} \\
(0.00)\end{array}$ & $\begin{array}{c}0.008^{* *} \\
(0.00)\end{array}$ & $\begin{array}{c}0.010^{\star *} \\
(0.00)\end{array}$ & $\begin{array}{l}0.004^{*} \\
(0.00)\end{array}$ & $\begin{array}{c}0.020^{\star *} \\
(0.01)\end{array}$ & $\begin{array}{c}0.009 * * \\
(0.00)\end{array}$ & $\begin{array}{c}0.008^{\star *} \\
(0.00)\end{array}$ & $\begin{array}{c}0.013^{\star *} \\
(0.00)\end{array}$ & $\begin{array}{c}0.011^{* *} \\
(0.00)\end{array}$ \\
\hline Liquidity $3 /$ & $\begin{array}{l}0.016 \\
(0.01)\end{array}$ & $\begin{array}{l}0.037 \\
(0.03)\end{array}$ & $\begin{array}{l}0.016 \\
(0.01)\end{array}$ & $\begin{array}{l}-0.011 \\
(0.02)\end{array}$ & $\begin{array}{l}0.008 \\
(0.01)\end{array}$ & $\begin{array}{l}0.009 \\
(0.01)\end{array}$ & $\begin{array}{l}-0.006 \\
(0.02)\end{array}$ & $\begin{array}{l}0.019 \\
(0.02)\end{array}$ & $\begin{array}{l}0.005 \\
(0.01)\end{array}$ & $\begin{array}{l}-0.003 \\
(0.02)\end{array}$ & $\begin{array}{l}0.006 \\
(0.02)\end{array}$ \\
\hline Leverage $4 /$ & $\begin{array}{l}0.001 \\
(0.00)\end{array}$ & $\begin{array}{l}0.002 \\
(0.00)\end{array}$ & $\begin{array}{l}0.002^{*} \\
(0.00)\end{array}$ & $\begin{array}{l}0.000 \\
(0.00)\end{array}$ & $\begin{array}{l}0.001 \\
(0.00)\end{array}$ & $\begin{array}{l}-0.000 \\
(0.00)\end{array}$ & $\begin{array}{l}0.001 \\
(0.00)\end{array}$ & $\begin{array}{l}-0.001 \\
(0.00)\end{array}$ & $\begin{array}{l}-0.000 \\
(0.00)\end{array}$ & $\begin{array}{l}-0.001 \\
(0.00)\end{array}$ & $\begin{array}{l}0.001 \\
(0.00)\end{array}$ \\
\hline \multirow[t]{2}{*}{ Uncertainty $5 /$} & $\begin{array}{c}-0.029 \\
(0.03)\end{array}$ & $\begin{array}{l}-0.289 \\
(0.18)\end{array}$ & $\begin{array}{c}-0.032 \\
(0.03)\end{array}$ & $\begin{array}{c}-0.068^{*} \\
(0.04)\end{array}$ & $\begin{array}{l}-0.036 \\
(0.04)\end{array}$ & $\begin{array}{c}-0.062^{\star \star} \\
(0.03)\end{array}$ & $\begin{array}{l}-0.076 \\
(0.07)\end{array}$ & $\begin{array}{c}-0.056^{*} \\
(0.03)\end{array}$ & $\begin{array}{l}0.011 \\
(0.04)\end{array}$ & $\begin{array}{c}-0.095^{\star *} \\
(0.05)\end{array}$ & $\begin{array}{l}-0.046 \\
(0.04)\end{array}$ \\
\hline & \multicolumn{11}{|c|}{ ( $\mathrm{p}$-value of specification tests) } \\
\hline $\mathrm{m} 1$ & 0.000 & 0.000 & 0.000 & 0.000 & 0.000 & 0.000 & 0.000 & 0.000 & 0.000 & 0.000 & 0.000 \\
\hline $\mathrm{m} 2$ & 0.112 & 0.346 & 0.128 & 0.929 & 0.277 & 0.148 & 0.336 & 0.355 & 0.231 & 0.177 & 0.164 \\
\hline Hansen-test & 0.141 & 0.267 & 0.335 & 0.225 & 0.332 & 0.171 & 0.375 & 0.633 & 0.433 & 0.207 & 0.499 \\
\hline Number of firms & 5252 & 2656 & 4295 & 2281 & 3263 & 3073 & 2179 & 2726 & 2797 & 2542 & 2710 \\
\hline Number of observations & 29039 & 9370 & 19669 & 14640 & 12493 & 18621 & 10418 & 13248 & 12593 & 15418 & 13621 \\
\hline $\begin{array}{l}\text { Source: Worldscope and } \\
\text { 1/ First-differenced GMM } \\
\text { 2/ Robust t-statistics in pa } \\
\text { 3/ Cash flow to capital. } \\
\text { 4/ Debt-to-assets. } \\
\text { 5/ Standard deviation of } r\end{array}$ & eturn on week & index & alized). & cent a & at $5 p$ & 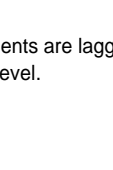 & theleng & ssors. & & & \\
\hline
\end{tabular}




\section{Results: R\&D Spending}

Intangible investment is also driven by economic fundamentals, although estimated impacts are somewhat smaller than for fixed investment. Estimating equation (1) on our full sample of R\&D investing firms yielded the following results (Table 4):

\begin{tabular}{|c|c|c|c|c|c|c|c|c|c|}
\hline & \multirow[t]{2}{*}{ Full Sample } & \multicolumn{2}{|c|}{ Size } & \multicolumn{2}{|c|}{ Market exposure } & \multicolumn{2}{|c|}{ Factor intensity } & \multicolumn{2}{|c|}{ Sector } \\
\hline & & Big & Small & Exporters & Domestic & Capital & Labor & Manufacturing & Services \\
\hline Tobin's Q & $\begin{array}{l}0.003^{*} \\
(0.00)\end{array}$ & $\begin{array}{l}0.003^{\star} \\
(0.00)\end{array}$ & $\begin{array}{c}0.005^{* *} \\
(0.00)\end{array}$ & $\begin{array}{c}0.005^{\star *} \\
(0.00)\end{array}$ & $\begin{array}{l}0.003 \\
(0.00)\end{array}$ & $\begin{array}{c}0.010^{\star *} \\
(0.00)\end{array}$ & $\begin{array}{l}0.003 \\
(0.00)\end{array}$ & $\begin{array}{l}0.003^{*} \\
(0.00)\end{array}$ & $\begin{array}{l}0.001 \\
(0.00)\end{array}$ \\
\hline Liquidity $3 /$ & $\begin{array}{l}0.003 \\
(0.03)\end{array}$ & $\begin{array}{l}-0.024 \\
(0.04)\end{array}$ & $\begin{array}{c}0.082^{\star *} \\
(0.03)\end{array}$ & $\begin{array}{l}0.004 \\
(0.03)\end{array}$ & $\begin{array}{l}0.077^{*} \\
(0.04)\end{array}$ & $\begin{array}{l}0.007 \\
(0.06)\end{array}$ & $\begin{array}{c}0.080^{\star *} \\
(0.04)\end{array}$ & $\begin{array}{l}-0.011 \\
(0.03)\end{array}$ & $\begin{array}{c}0.108^{* *} \\
(0.04)\end{array}$ \\
\hline Leverage $4 /$ & $\begin{array}{c}-0.001^{*} \\
(0.00)\end{array}$ & $\begin{array}{l}-0.000 \\
(0.00)\end{array}$ & $\begin{array}{l}0.000 \\
(0.00)\end{array}$ & $\begin{array}{l}-0.001 \\
(0.00)\end{array}$ & $\begin{array}{l}0.000 \\
(0.00)\end{array}$ & $\begin{array}{c}-0.001^{* *} \\
(0.00)\end{array}$ & $\begin{array}{c}-0.002^{* *} \\
(0.01)\end{array}$ & $\begin{array}{l}0.000 \\
(0.00)\end{array}$ & $\begin{array}{c}-0.002^{\star \star} \\
(0.00)\end{array}$ \\
\hline \multirow[t]{2}{*}{ Uncertainty $5 /$} & $\begin{array}{l}0.027 \\
(0.02)\end{array}$ & $\begin{array}{c}-0.057^{* *} \\
(0.03)\end{array}$ & $\begin{array}{l}0.003 \\
(0.03)\end{array}$ & $\begin{array}{l}0.037 \\
(0.04)\end{array}$ & $\begin{array}{l}0.029 \\
(0.04)\end{array}$ & $\begin{array}{l}-0.039 \\
(0.03)\end{array}$ & $\begin{array}{l}-0.039 \\
(0.04)\end{array}$ & $\begin{array}{l}0.031 \\
(0.03)\end{array}$ & $\begin{array}{l}-0.002 \\
(0.04)\end{array}$ \\
\hline & \multicolumn{9}{|c|}{ ( $\mathrm{p}$-value of specification tests) } \\
\hline $\mathrm{m} 1$ & 0.000 & 0.000 & 0.001 & 0.004 & 0.001 & 0.000 & 0.000 & 0.025 & 0.022 \\
\hline $\mathrm{m} 2$ & 0.779 & 0.190 & 0.984 & 0.480 & 0.324 & 0.079 & 0.152 & 0.295 & 0.502 \\
\hline Hansen-test & 0.340 & 0.352 & 0.708 & 0.123 & 0.963 & 0.414 & 0.755 & 0.101 & 0.976 \\
\hline Number of firms & 1804 & 824 & 1019 & 890 & 914 & 906 & 931 & 1412 & 392 \\
\hline Number of observations & 6558 & 3283 & 2735 & 3935 & 2623 & 2988 & 2853 & 5381 & 1177 \\
\hline \multicolumn{10}{|c|}{ Source: Worldscope and Fund staff calculations. } \\
\hline \multicolumn{10}{|c|}{$\begin{array}{l}\text { 1/ First-differenced GMM specifications, with lagged dependent variable and year dummies. Instruments are lagged values of regressors. } \\
\text { 2/ Robust t-statistics in parentheses, with * indicating significance at } 10 \text { percent and ** at } 5 \text { percent level. } \\
3 \text { / Cash flow to capital. } \\
\text { 4/ Debt-to-assets. } \\
5 \text { / Standard deviation of return on weekly price index (annualized). }\end{array}$} \\
\hline
\end{tabular}

- $\quad$ Profitability. R\&D spending is positively associated with expectations of future profitability, as summarized by Tobin's Q, with an implied elasticity of around 0.1.

- $\quad$ Leverage. $\mathrm{R} \& \mathrm{D}$ spending is negatively associated with leverage, with an implied elasticity of -0.2 .

- $\quad$ Cash flow and uncertainty. The coefficient on cash flow is positive but insignificant, much like in our full sample for fixed investment, as is that on uncertainty. Together with the lower implied elasticities on Tobin's Q and leverage, this could reflect the fact that R\&D spending typically involves significant sunk and adjustment costs, which tend to make it less sensitive to shocks that are perceived to be short-lived (see, for example, Bond and others, 2003). A priori, however, since investment in intangible assets tends to be riskier and harder to collateralize, such spending may be more prone to financing constraints and we explore this further in our sample splits.

Again, we detected a dichotomy between firms and economically significant effects (Figure 13):

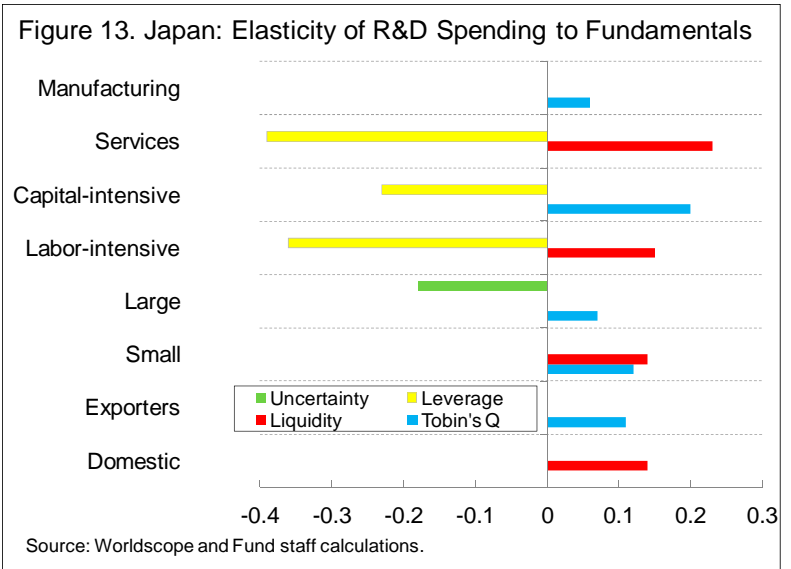


- $\quad$ Large firms. For larger firms, manufacturers and exporters, R\&D spending is driven by profit expectations and not affected by cash flow or financing structure. In addition, uncertainty tends to dampen such spending by large firms.

- $\quad S M E s$. By contrast, for smaller, service sector, and non-exporting firms, financing constraints hinder R\&D spending, and, by extension, innovation.

- $\quad$ Leverage. The effect of financing structure was less pervasive than for fixed investment. However, reliance on debt financing does hold back R\&D spending in services, suggesting that greater equity financing could spur innovation within this sector.

\section{Policy Implications}

As labor input shrinks with population aging, capital accumulation and productivity gains will drive growth over the medium-term. What policies could be adopted to help firms adjust to the imperatives of the post-crisis global economy? Our results suggest that underlying strategies for supporting investment and innovation will differ depending on firm characteristics and sectors. As discussed below, policies could usefully focus on four areas: (i) increasing the return on investment; (ii) strengthening risk management to reduce uncertainty; (iii) improving access to external financing to reduce the cost of capital, especially for smaller and domestically-oriented firms; and (iv) reducing excess leverage and promoting SME restructuring to create space for new investment.

First, raising the rate of return on investment will be important. The tax code is an obvious candidate, since taxes raise the bar for investment to be profitable and fall especially hard on capital-intensive industries. Moreover, tax reforms have been shown to have significant effects on investment in advanced economies (Cummins, Hassett, and Hubbard, 1995).

- $\quad$ Reducing the corporate tax rate. In addition to the headline statutory rate of corporate tax, which at 40 percent is the highest in the OECD, the average and marginal effective rates (AER and MER) are important in determining the location and level of investment, respectively. ${ }^{15}$ Japan also has the highest AER and the second-highest MER on equityfinance investments (Figure 14). Reducing the corporate tax rate may, therefore, be an effective strategy for reducing distortions and boosting both domestic and foreign investment in Japan.

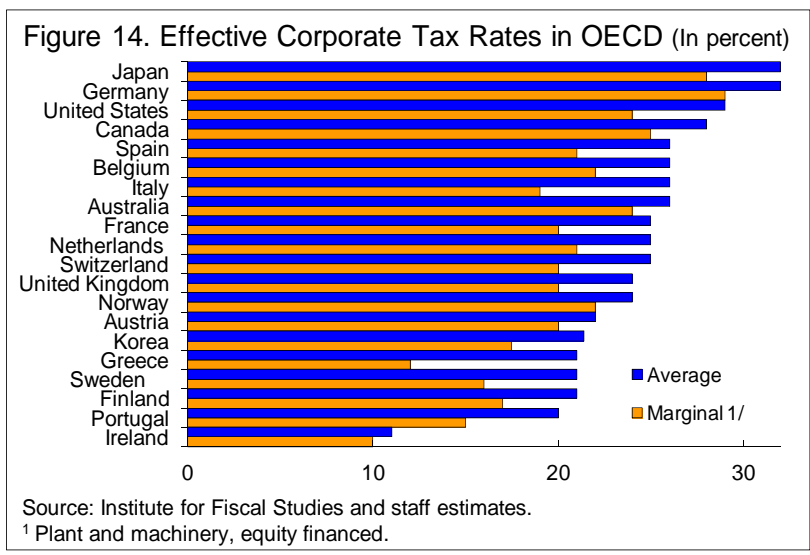

\footnotetext{
${ }^{15}$ The average effective rate is the proportion of lifetime pre-tax profit that is taken in tax, while the marginal effective tax rate is the difference between the before- and after-tax returns on a project that an investor finds just worthwhile.
} 
- $\quad$ Extending corporate tax-loss carry forwards could help firms recoup some of the losses incurred in the early years of large investments—Japan currently allows for a 7 year carry forward period, compared to 20 years in the United States (Table 5). Currently, Japanese firms are facing low expectations for corporate profitability and will likely need a longer time to generate

\begin{tabular}{|lcc|}
\hline \multicolumn{3}{c|}{ Table 5. Tax-Loss Carry Forwards } \\
\hline (Years) & Carry Forward & Carry Back \\
\hline Australia & Indefinite & 0 \\
Canada & 10 & 3 \\
Japan & 7 & 1 \\
Netherlands & Indefinite & 3 \\
New Zealand & Indefinite & 0 \\
Spain & 15 & 0 \\
United Kingdom & Indefinite & 1 \\
United States & 20 & 2 \\
Source: Australian Treasury. & \\
\hline
\end{tabular}
profits and recoup losses amid weak growth prospects and persistent deflationary pressures. Therefore, extending the tax loss carry forward could provide an incentive for investment, although the impact on corporate tax revenue would also need to be carefully considered.

- $\quad$ Increasing tax credits or targeted public spending, such as the support of research programs by the government in Germany, could help spur more innovation (see, for example, Bloom, Griffith, and Van Reenen, 2002). At 10 and 20 cents per dollar of R\&D spending for large firms and SMEs, respectively, tax subsidies are moderate in Japan compared to some other advanced

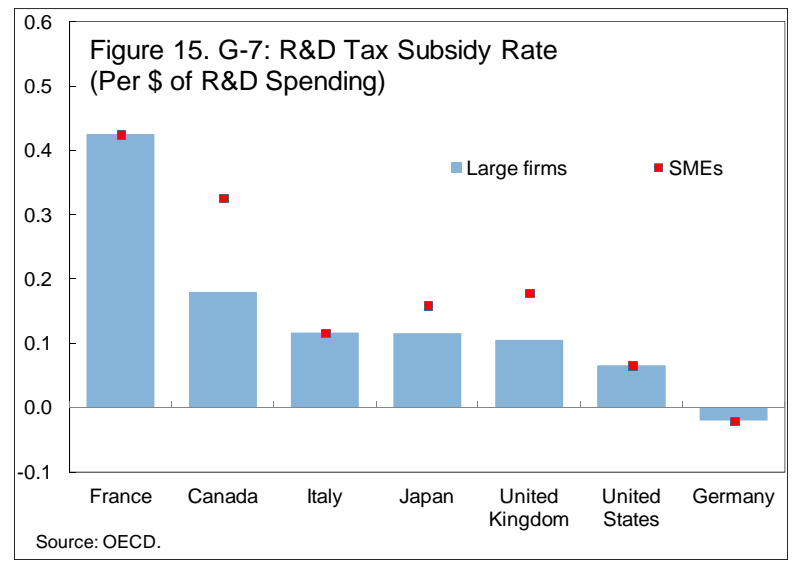
economies (Figure 15).

Second, reducing uncertainty would help lower the risks associated with long-term investment decisions. Investment decisions can be affected by uncertainty about many, potentially exogenous, aspects of their operating environment—such as demand, prices, costs, and exchange rates_-as well as risk related to policies. Potential options include:

- $\quad$ Promoting the use of financial instruments to manage risks. International comparisons suggest that while large exporters in Japan engage in significant hedging activity they tend to under-insure against credit, commodity and marketable security price risk. By contrast, SMEs undertake much less hedging, including of exchange rate and interest rate risk (Heaney and others, 1999, and Bartram and others, 2003).

- $\quad$ Further improvements to the business climate. International surveys of investor perceptions suggest that a more streamlined process for business creation ${ }^{16}$, more

\footnotetext{
${ }^{16}$ According to the World Bank's Doing Business 2011, Japan ranks $25^{\text {th }}$ out of 30 OECD countries in terms of starting a new company due to the number, time and cost of procedures.
} 
labor market flexibility ${ }^{17}$, and improved legal and regulatory framework for entrepreneurs and bankruptcy could help reduce investor perceptions of risk in Japan.

Third, improving access to external financing would lower the cost of capital for smaller firms and those in the service sector. Problems faced by SMEs in accessing financing typically reflect an incomplete range of financial products, regulatory rigidities, gaps in the legal framework, or information asymmetries between financers and firms. These problems are especially acute for start-ups, which represent an important source of innovation and will become even more important as production processes are revamped in response to a changed post-crisis global landscape. However, business creation in Japan is low ${ }^{18}$ and the venture capital industry still in an early stage of development-Japan ranks second last in the OECD in venture capital investment as a share of GDP (Figure 16). ${ }^{19}$ Investors are also skewed toward banks and other financial institutions, with pension funds playing a much more limited role, unlike in the United States and Europe (Figure 17). This make-up may bias venture capital toward late-stage development rather than seed and start-up companies (Mayer, Schoors, and Yafeh, 2005) and toward shorter-term investments. In addition, less than a third of venture capital investments is directed toward leading science-based sectors-such as communications, IT and biotechnology-compared to 90 percent in the United States. Policy options include:
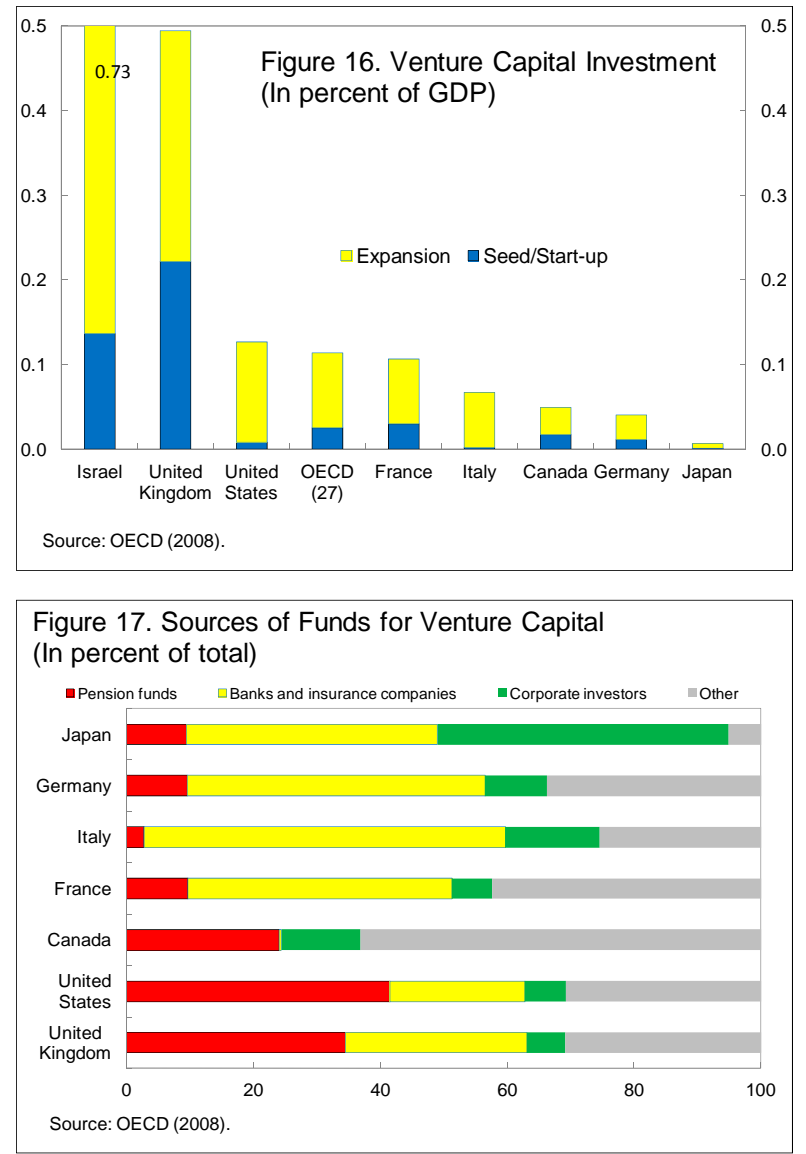

- $\quad$ Widening the pool of venture capital funding available for start-ups in new emerging sectors, (OECD, 2006b). Targeted tax breaks or allocating a larger share of the public pension funds to venture capital investments could support the industry. ${ }^{20}$ Providing

\footnotetext{
${ }^{17}$ Japan is ranked tenth in employment protection in the OECD (OECD, 2006b) and first among major industrial countries in the difficulty of dismissing workers (World Bank, 2009).

${ }^{18}$ Possible impediments include government regulations and credit market imperfections (see Mukoyama, 2009).

${ }^{19}$ At 5.1 percent, the opening rate is lower than the 6.2 percent closing rate and the more than 10 percent opening rates in France, United Kingdom, and the United States.

${ }^{20}$ Presently, the GPIF does not undertake any alternative investments such as venture capital, real estate and private equity. By contrast, a number of OECD countries allocate some share of their assets to such investments, including CalPERS (14 percent), New Zealand Superannuation Fund (11 percent), Government of Singapore Investment Corporation (11 percent), and Korea National Pension Service Fund (2.5 percent).
} 
greater information to potential institutional investors through a database documenting investment performance records of venture firms ${ }^{21}$ and development of performance benchmarks on emerging equity exchanges (such as JASDAQ) could draw in more investment (Figure 18).

- $\quad$ Broadening eligible collateral to allow for a wider range of securitization beyond real estate and fixed asset, including intellectual property rights and receivables. The authorities are already moving in this direction of promoting asset-based lending-the Credit Guarantee Corporation and Japan Finance Corporation have initiated a program accepting inventories and accounts

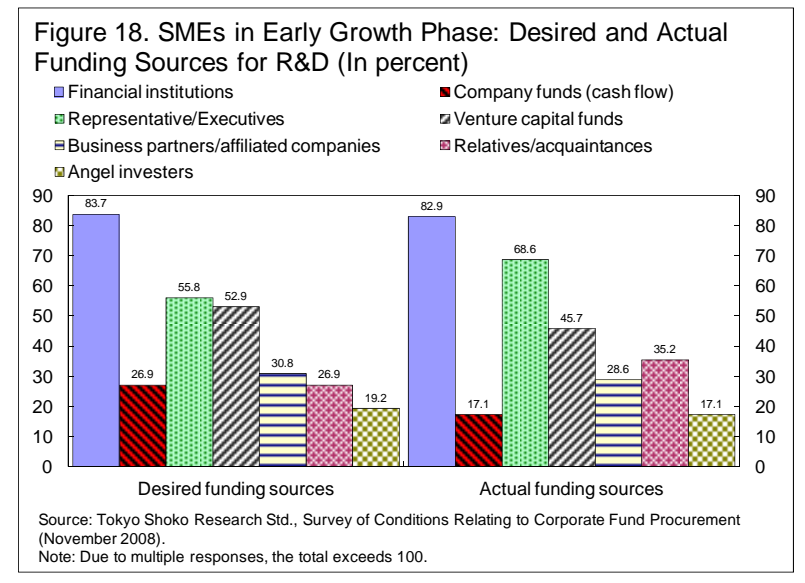
receivables as collateral since 2007.

- $\quad$ Greater risk-based lending. Banks traditionally rely heavily on collateral or relationship lending to guide their credit decisions, which can undermine financial intermediation. ${ }^{22} \mathrm{~A}$ broader sharing of borrower's credit information and developing private institutions for credit insurance could strengthen banks' risk management and expand risk-based lending.

Fourth, reducing leverage and improving incentives for corporate restructuring will help create space for new investment.

- $\quad$ As the recovery firms, restructuring could be promoted by phasing out credit guarantees. Significant progress has been made on corporate and financial restructuring over the last decade, but smaller companies have tended to fall behind. This partly reflects the still-sizable credit guarantees for SMEs, which can limit their incentives for restructuring and create an entry barrier by making it difficult for many newer firms to access bank credit (McKinsey Global Institute, 2000). ${ }^{23}$

\footnotetext{
${ }^{21}$ In the United States and Europe, VentureOne and Thomson Financial store information on start-upsincluding profitability and investment flows-regularly used by venture capitalists and institutional investors.

${ }^{22}$ According to the OECD, cross share-holding has limited risk-taking, while the rise in the share of loans by public financial institutions (15 percent in early 1990s to 20 percent) may have hindered the development of capital market to supply risk money and prevented the exit of less competitive firms. According to the BoJ's March 2010 Financial Systems Report, firms with strong capital ties to banks have tended to underperform in terms of profitability and liquidity indicators.

${ }^{23}$ Uesugi, Sakai, and Yamashiro (2006) suggest that credit guarantees can lead to a significant increase in leverage and do not translate into efficiency gains in the case of high-risk firms.
} 
- $\quad$ Assisting the exit of nonviable companies, through out-of-court workouts and further reforms to streamline bankruptcy procedures. ${ }^{24}$ Combined with reforms to the public support system, these measures could jumpstart a market for private-led restructuring of distressed SMEs, similar to what took place for large enterprises after Japan's 1990s banking crisis.

- $\quad$ Facilitate FDI to increase equity financing, promote links with global production networks and enable technology transfer. FDI flows into Japan are currently very low, limiting opportunities to gain access to new technologies especially for SMEs, particularly in the services sector (Figure 19).

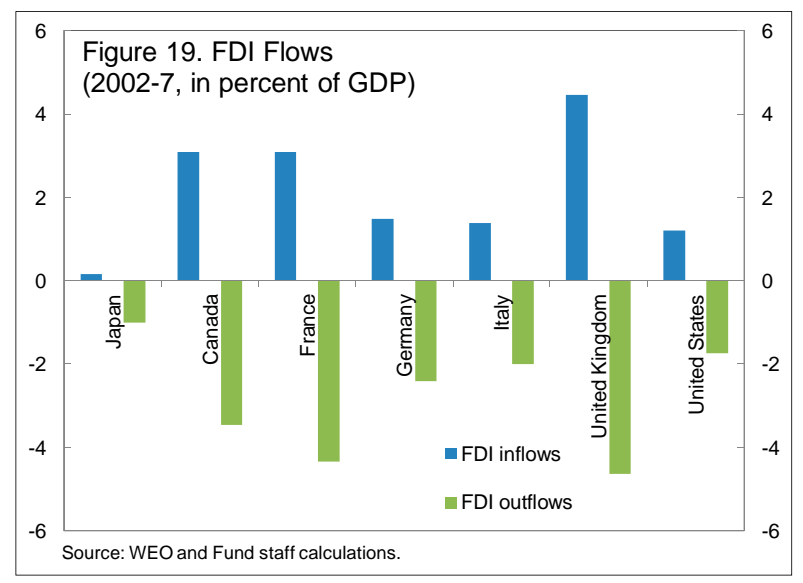

\section{Conclusion}

In Japan, public policies can help create an environment for more effective capital formation. A shrinking domestic labor force places an onus on capital accumulation and innovation to ensure robust growth over the medium-term. At the same time, a changing global landscape calls for a shift in export-oriented investment toward new markets and a new generation of products, as well as increased investment by domestically-oriented firms. To support this transition, policies could usefully focus on four broad areas. First, raising the return on investment, including through reforms to the tax code. Second, decreasing uncertainty through improved risk management by firms and by bolstering the business climate. Third, improving SME access to finance, notably by encouraging venture capital investment in innovative areas and more risk-based lending. And fourth, reducing excess leverage and supporting SME restructuring to enable new investments to flourish. Such reforms would not only strengthen the growth foundations of the Japanese economy but also help capitalize on changes taking place in the global environment.

\footnotetext{
${ }^{24}$ Over the longer term, attention should shift away from relying on guarantees to addressing the root cause of SMEs' limited access to credit—research suggests that improvements in the financial infrastructure can improve credit availability, including by expanding credit information sharing, allowing the securitization of movable assets, and developing venture capital markets for SMEs (Beck and Demirgüç-Kunt, 2006).
} 


\begin{abstract}
APPENDIX
The data used in the empirical analysis include all listed nonfinancial firms in our selected jurisdictions covered in the Worldscope database during the period 1990-2008. The Worldscope database is well-known for its standardized presentation of global investment portfolios and its good coverage of historical data. The database covers over 96 per cent of the world's market value represented by it. One important advantage of using the database is that it provides standardized data for countries with different reporting practices, yielding relatively more reliable cross-country comparisons. Several firms entered the data set after 1995, implying somewhat shorter series for them. Outliers were excluded from the analysis based on standard criteria.

The company-specific variables included are those that potentially affect firm-level investment decisions, as suggested by the standard model of investment outlined in section III. These variables are obtained primarily from cash flow statements and include expected future profitability (Tobin's Q), cash flow, sales growth, leverage (defined as total debt to total assets) and uncertainty (measured as the standard deviation of returns on the weekly stock price index for the firm). The capital stock measure was estimated using the standard perpetual inventory method, with the net book value of plant, property, and equipment was treated as the starting value, and subsequent values determined using data on investment, disposals, and acquisitions.
\end{abstract}

Incorporating the standard adjustments for debt, Tobin's $Q$ is defined as:

$$
Q_{i t}=\left[\frac{V_{i t}+B_{i t}-C_{i t}}{p_{t}(1-\delta) K_{i, t-1}}\right]
$$

where $V$ is the firm's fundamental value or the expected present discounted value of future payments to shareholders; $B$ is the book value of its outstanding debt; $C$ is current assets; $p$ is the price of the investment good; $\delta$ is the capital depreciation rate (assumed to equal 8 percent); and $K$ is the replacement value of the firm's capital stock. 


\section{REFERENCES}

Bank of Japan, 2003, Recent Trends in Business Fixed Investment and the Issues Attending a Full Recovery: Restoring Firms' Capacity to Generate Capital Investment, Quarterly Bulletin, November.

Beck, Thorsten and Asli Demirgüç-Kunt, 2006, "Small and Medium-Size Enterprises: Access to Finance as a Growth Constraint,” Journal of Banking and Finance, Vol. 30, pp. 2931-2943.

Brandstetter, Lee and Yoshiaki Nakamura, 2003, “Is Japan’s Innovative Capacity in Decline?,” NBER Working Paper No. 9438, (Cambridge, Massachusetts).

Bloom, Nicholas, Rachel Griffith, and John Van Reenen, 2002, “Do R\&D Tax Credits Work? Evidence from a Panel of Countries 1979-97,” Journal of Public Economics, Vol. 85, pp. 1-31.

Bond, Stephen, Dietmar Harhoff, and John Van Reenen, 2003, “Investment, R\&D and Financial Constraints in Britain and Germany”, LSE CEP Discussion Paper No. 595.

Cummins, Jason G., Kevin A. Hassett, and R. Glenn Hubbard , 1995, “Tax Reforms and Investment: A Cross-Country Comparison,” Journal of Public Economics Vol. 62, pp. 237-73.

Dixit, Avinash K., and Robert S. Pindyck, 1994, Investment under Uncertainty, Princeton, (New Jersey, Princeton University Press).

Hayashi, Fumio and Edward C. Prescott, 2002, “The 1990s in Japan: A Lost Decade”, Review of Economic Dynamics, Vol. 5, pp. 206-235.

Heaney, Richard, Chitoshi Koga, Barry Oliver, and Alfred Tran, 1999, “The Size Effect and Derivative Usage in Japan,” Working Paper: The Australian National University.

Imai, Yutaka and Masaaki Kawagoe, 2000, “Business Start-ups in Japan: Problems and Policies.” Oxford Review of Economic Policy, Vol.16, No. 2, pp. 114-23.

Jones, Randall S., and Taesik Yoon, 2006, "Strengthening the Integration of Japan in the World Economy to Benefit More Fully from Globalization,” OECD Economics Department Working Papers, ECO/WKP(2006)54, November

Kang, Kenneth, 2003, Health and Vulnerability of the Corporate Sector in Japan, in Selected Issues, IMF Country Report 03/282 (Washington: International Monetary Fund).

Komori, Takuo, 2004, Recovery of Japanese Firms, in Selected Issues, IMF Country Report 04/247 (Washington: International Monetary Fund). 
Mayer, Colin, Koen Schoors, and Yishay Yafeh, 2003, "Sources of Funds and Investment Activities of Venture Capital Funds: Evidence from Germany, Israel, Japan and the U.K.,” Journal of Corporate Finance, Vol. 11.

McKinsey Global Institute, 2000, "Why the Japanese Economy is Not Growing: Micro Barriers to Productivity Growth,” July.

Mukoyama, Toshihiko, 2009, “On the Establishment Dynamics in the United States and Japan,” Monetary and Economic Studies, Vol. 27, November, pp. 53-74.

Nicoletti, Giuseppe and Stefano Scarpetta, 2005, "Regulation and Economic Performance: Product Market Reforms and Productivity in the OECD,” OECD Economics Department Working Papers 460.

Organisation for Economic Co-operation and Development, 2005, “OECD Economic Survey of Japan.”

— , 2006a, “OECD Economic Survey of Japan.”

—_, 2006b, “OECD Economic Policy Reforms: Going for Growth.”

—_, 2008, “OECD Science, Technology, and Industry Scoreboard.”

Sakakibara, Kiyonori and Masaharu Tsujimoto, 2003, "Why Did R\&D Productivity of Japanese Firms Decline?” ESRI Discussion Paper Series No. 47, Economic and Social Research Institute, Cabinet Office.

Steinberg, Chad, 2009, Current Challenges Facing SMEs in Japan, in Selected Issues. IMF Country Report 09/211 (Washington: International Monetary Fund).

Takeishi, Akira and Takahiro Fujimoto, 2003, "Modularization in the Car Industry: Interlinked Multiple Hierarchies of Product, Production and Supplier Systems,” in The Business of Systems Integration, A. Prencipe, ed. by A. Davies and M. Hobday (Oxford: Oxford University Press).

Uesugi, Iichiro, Koji Sakai, and Guy Yamashiro, 2006, "Effectiveness of Credit Guarantees in the Japanese Loan Market," RIETI Discussion Paper Series (06-E-004), February.

World Bank, 2009, “Doing Business Indicators,” (Washington: World Bank). 